\title{
MUC1 IMMUNOTHERAPY AGAINST A METASTATIC MAMMARY ADENOCARCINOMA MODEL: IMPORTANCE OF IFN-GAMMA
}

\section{Catherine J. Lees ${ }^{1}$, Nechama Smorodinsky², Galit Horn², Daniel H. Wreschner ${ }^{2}$, Ian F.C. McKenzie $^{3}$, Geoffrey Pietersz ${ }^{4,5,6}$, Lily Stojanovska ${ }^{7}$, Vasso Apostolopoulos ${ }^{7, *}$}

${ }^{1}$ Current Address, Echuca Regional Health, Echuca VIC Australia

${ }^{2}$ Department of Cell Research and Immunology, Tel Aviv University, Tel Aviv, Israel

${ }^{3}$ Current Address, Emeritus Professor, University of Melbourne, VIC Australia

${ }^{4}$ Bio-organic and Medicinal Chemistry Laboratory, Burnet Institute, VIC Australia

${ }^{5}$ Department of Pathology, University of Melbourne, Parkville, Victoria, Australia

${ }^{6}$ Department of Immunology, Monash University, Melbourne, Victoria, Australia

${ }^{7}$ Centre for Chronic Disease, College of Health and Biomedicine, Victoria University, VIC Australia

* Corresponding Author: Vasso Apostolopoulos, Centre for Chronic Disease, College of Health and Biomedicine, Victoria University, VIC Australia. Tel: +613 99192025; Fax: +61399194565

E-mail: vasso.apostolopoulos@vu.edu.au

\begin{abstract}
Immunotherapy using mucin 1 (MUC1) linked to oxidised mannan (MFP) was investigated in an aggressive $\mathrm{MUC1}^{+}$metastatic tumour, DA3-MUC1 because, unlike many $\mathrm{MUC1}^{+}$tumour models, DA3-MUC1 is not spontaneously rejected in mice making it an alternative model for immunotherapy studies. Further, DA3-MUC1 cells are resistant to lysis by anti-MUC1 cytotoxic T cells (CTLs). The inability of DA3-MUC1 tumours to be rejected in naïve mice as well as vaccination to MUC1 was attributed to a deficiency of expression of MHC class I molecules on the tumour cell surface. In vitro and in vivo analysis of subcutaneous tumours and lung metastases demonstrated that DA3-MUC1 tumour cells have a low expression $(<6 \%)$ of MHC class I which can be upregulated (> 90\%) following culturing with IFN- $\gamma$. Results from flow cytometry analysis and immunoperoxidase staining indicated that the in vitro up-regulation of MHC class I could be maintained for up to seven days in vivo, without affecting the expression levels of MUC1 antigen. Interestingly, MUC1-specific CTL that lyse DA3-MUC1 targets in vitro were induced in MFP immunised mice but failed to protect mice from a DA3-MUC1 tumour challenge. These results highlight the importance of MHC class I molecules in the induction of anti-tumour immunity and the MFP immune response.
\end{abstract}

Keywords: MUC1. MHC class I, interferon-gamma, tumour, immunotherapy

\section{Introduction}

Anti-tumour immunity and tumour eradication are induced by cell-mediated immune responses $[1,2]$. The activation of tumour-specific $\mathrm{CD}^{+} \mathrm{T}$ lymphocytes and their subsequent differentiation into cytolytic cells is dependent on 2 signals from the antigen-presenting cell. One signal is provided through the interaction of the antigenic peptide (from the tumour) pre- sented on the major histocompatibility complex (MHC) to T cells. The other is the costimulatory signals, efficiently provided by $\mathrm{B} 7$ [B7-1 (CD80) and B7-2 (CD86)] binding to CD28 (CD152 or CTLA-4) on T cells [3, 4]. However, malignant cells have evolved mechanisms enabling them to successfully evade the immune system, which in many cases directly affects this 2 signal process. These mechanisms 
include inadequate expression of costimulatory molecules, Fas ligand, or adhesion molecules on cancer cells, antigen processing defects, the secretion of inhibitory molecules into the tumour microenvironment or absent or poorly expressed MHC molecules on the tumour cell surface [5-7]. More recently, it has been demonstrated that tumour cells have additional escape mechanisms by expressing PD-L1 (B7H1, CD275) and/or PD-L2 on their surface, which upon binding to its ligand, PD-1, expressed by activated $\mathrm{CD}^{+} \mathrm{T}$ cells leads to apoptosis of T cells [8].

The failure of tumours to adequately process antigens and present peptide fragments to $\mathrm{T}$ cells is greatly attributed to reduced expression of MHC class I molecules on the cell surface of tumour cells $[5,6,9,10]$. In many tumour models however, this can be rectified transfecting tumour cells with MHC class I gene $[11,12]$. Another approach is to transfect cytokine cDNA, in particular IFN- $\gamma$, into tumours as it directly causes an up-regulation of cell surface MHC class I expression [11, 13].

This study characterises the DA3-MUC1 metastatic tumour following the failure of mannan-MUC1 (MFP) immunisations to induce anti-tumour immunity in this $\mathrm{MUC1}^{+}$cancer model. It was demonstrated that DA3-MUC1 was non-immunogenic due to an absence of MHC class I expression on the tumour cell surface, which could be upregulated by IFN- $\gamma$ but not sustained long enough in vivo to cause tumour eradication.

\section{Materials and methods \\ Mice and immunisations}

A MUC1-GST fusion protein containing 5 variable number of tandem repeat (VNTR) regions from the extracellular protein core of MUC1 [14] was produced in a bacterial expression system (pGEX-3X) and conjugated to oxidised mannan to form MFP as described previously [15-23]. BALB/c mice aged 6-10 weeks were given three intraperitoneal immunisations (on days 0, 7 and 14) with either MFP (containing $5 \mu \mathrm{g}$ of MUC1 fusion protein) or a control pH 9.0 phosphate buffer. BALB/c mice immunised with mannan coupled to oxidised GST (M-GST) were included as controls in the lung metastases study. All experiments were approved by the Austin Animal Ethics Committee.

\section{Cell lines}

DA3-MUC1 is a metastatic BALB/c DA3 mammary cell line transfected with the cDNA of the transmembrane form of human MUC1 [24, 25]; P815-MUC-1, a DBA/2 P815 mastocytoma cell lines transfected with the cDNA of the transmembrane form of human MUC1 [26, 27] were cultured in RPMI and MUC1 expression selected for every 14-20 days with $1.25 \mathrm{mg} / \mathrm{ml} \mathrm{G} 418$-sulfate (Gibco BRL, U.S.A).

\section{Flow cytometry}

The expression of cell surface molecules on DA3-MUC1 were measured by flow cytometry. The following monoclonal antibodies were used; a) MUC1 (BC2: supernatant) [28], b) MHC class $1 \mathrm{H}^{\mathrm{d}}{ }^{\mathrm{d}}$ (34.1.2s, $1 / 1000$ dilution of ascites fluid) [29], c) MHC class II I-A8 (1/500 dilution of ascites fluid), d) B7.1 ( $4 \mu \mathrm{g})$ (Pharmingen, San Diego, USA), e) ICAM-2 $(1 \mu \mathrm{g})$ (Pharmingen), f) CD28 $(4 \mu \mathrm{g})$ (Pharmingen), g) LFA-2 (1 $\mu \mathrm{g})$ (Pharmingen) and $\mathrm{h}$ ) CTLA-4 $(1 \mu \mathrm{g})$ (Pharmingen). DA3-MUC1 tumour cells were prepared for FACS analysis by either a) culturing in growth media, b) culturing with $20 \mathrm{ng} / \mathrm{ml}$ vaccinia virus-IFN- $\gamma$ [22] for $72 \mathrm{~h}$, or c) culturing with $20 \mathrm{ng} / \mathrm{ml}$ IFN- $\gamma$ for $72 \mathrm{~h}$ and then removing IFN- $\gamma$ for subsequent culturing. In preparation for flow cytometry, tumour cells $\left(2-5 \times 10^{5}\right.$ cells $\left./ \mathrm{ml}\right)$ were incubated with the specified antibodies for 45 min at $4{ }^{\circ} \mathrm{C}$, washed with phosphate buffer and incubated with either FITC-conjugated sheep $(\text { Fab' })_{2}$ anti-mouse, anti-rat or anti-hamster immunoglobulin (Amersham, UK) (1/50 dilution) for a further $45 \mathrm{~min}$ at $4^{0} \mathrm{C}$. Cells were washed and analysed by flow cytometry.

\section{Immunoperoxidase staining of DA3-MUC1 tumour cells}

Cell surface expression of MUC1 and MHC class I proteins on DA3-MUC1 tumour cells in vivo were analysed by immunoperoxidase staining. DA3-MUC1 tumour cells were either, a) injected subcutaneously into BALB/c 
mice and grown for $>30$ days to establish lung metastasis. Mice were culled and samples taken from both the subcutaneous tumour site and from lung metastasis; or b) cultured with 20 $\mathrm{ng} / \mathrm{ml} \mathrm{IFN-} \gamma$ for $72 \mathrm{~h}$ and injected subcutaneously into BALB/c mice. Mice were culled and samples taken from the subcutaneous tumour site on days 4 and 7 and from lung metastasis > 30 days after injection.

All tissue samples were snap frozen in isopentane and sections 5-6 $\mu \mathrm{m}$ thick were cut using a Microm HM500 cryostat (MICROM Laborgerate, Strässe, Germany), mounted and fixed on silane coated slides [30]. Endogenous peroxidase activity was blocked by incubating with $0.5 \% \mathrm{H}_{2} \mathrm{O}_{2}$ for 40 minutes at room temperature. Tissue sections were incubated for 45 min at $4^{0} \mathrm{C}$ with biotinylated $\mathrm{BC} 2$ to detect MUC1 expression or biotinylated anti-H2 ${ }^{\mathrm{d}}$ (1/1000 dilution) to detect MHC class I expression. Excess antibodies were removed by thorough washing and samples incubated with streptavidin-HRP conjugate (Amersham, UK) (1/50 dilution) for a further $45 \mathrm{~min}$ at $4^{0} \mathrm{C}$. Antibody binding was detected with $1.5 \mathrm{mg} / \mathrm{ml} \mathrm{3-}$ 3 diaminobenzidine (DAB, Sigma, St. Louis, USA) in phosphate buffered saline containing $0.5 \% \mathrm{H}_{2} \mathrm{O}_{2}$ for $5 \mathrm{~min}$, slides were washed and mounted.

\section{Tumour model}

The immunogenicity of DA3-MUC1 tumour was characterised using the following tumour growth experiments and MFP immunisations.

(i) BALB/c mice (x 10) were subcutaneously injected with $5 \times 10^{6}$ DA3-MUC1 tumour cells and tumour growth measured with electronic callipers every week for 10 weeks to establish a DA3-MUC1 growth curve. Mice were sacrificed $>30$ days after the tumour challenge and lung metastasis determined by microscopically counting the number of metastasis present in random cross sections of similar sizes from formalin fixed lung samples (Anatomical Pathology Unit, Austin and Repatriation Medical Centre, VIC Australia).

(ii) $\mathrm{BALB} / \mathrm{c}$ mice (x 20 per group) were immunised 3 times on days 0,7 and 14 with either MFP $(5 \mu \mathrm{g})$ or M-GST $(5 \mu \mathrm{g})$ and chal- lenged with $5 \times 10^{6}$ subcutaneous DA3-MUC1 tumour cells. A minimum of 4 mice from each group were sacrificed each week for five weeks and the number of metastatic lesions present on each lung determined microscopically.

(iii) $\mathrm{BALB} / \mathrm{c}$ mice (x 10 per group) were injected subcutaneously with $5 \times 10^{6}$ DA3MUC1 tumour cells until tumours of $\sim 50 \mathrm{~mm}^{2}$ were established (Day 17). Mice were then immunised intraperitoneally on days 17, 19 and 21 with $5 \mu \mathrm{g}$ MFP. Tumour sizes were measured every 2-3 days for 30 days using electronic callipers.

(iv) $\mathrm{BALB} / \mathrm{c}$ mice (x 10 per group) were immunised intraperitoneally on days 0,7 and 14 with either $5 \mu \mathrm{g}$ MFP or $\mathrm{pH} 9.0$ buffer, and challenged subcutaneously on day 21 with $3 \mathrm{x}$ $10^{6}$ DA3-MUC1 tumour cells. Prior to challenge, the tumour cells were cultured with 20 $\mathrm{ng} / \mathrm{ml}$ vaccinia virus-IFN $\gamma$ supernatant (UV inactivated) $[22,23,25,26]$ for $72 \mathrm{~h}$ to increase cell surface MHC class I expression. Tumour growth was measured every 2-3 days for 2 weeks using electronic callipers.

\section{Cytotoxic $\mathbf{T}$ cell ${ }^{51} \mathrm{Cr}$ release assay}

BALB/c mice immunised (x 3) with MFP $(5 \mu \mathrm{g})$ were culled and their spleen cells collected and treated with $0.83 \% \mathrm{NH}_{4} \mathrm{Cl}$. Two-fold serial dilutions of effector spleen cells from the immunised mice were plated into a 96 well plate beginning at a concentration of $1 \times 10^{6}$ cells per well in duplicate. $1 \times 10^{4}{ }^{51} \mathrm{Cr}$ labelled DA3-MUC1 cells cultured with IFN- $\gamma$ (20 $\mathrm{ng} / \mathrm{ml}$ ) for $72 \mathrm{~h}$, DA3-MUC1, P815-MUC1 or P815 target cells were added to the effectors. The spontaneous release of ${ }^{51} \mathrm{Cr}$ from the labelled cells was determined by incubating target cells in RPMIM media and the maximum release was determined by incubation with $10 \%$ SDS (BDH Chemicals, Dorset, England). Cultures were incubated for $4 \mathrm{~h}$ before transferring $100 \mu \mathrm{l}$ of supernatant to 96 well flat Optiplates (Disposable Products, Australia) containing $100 \mu \mathrm{l}$ of Microscint 40 (Packard, USA) for analysis on the microplate scintillation counter (Packard USA). The specific percentage lysis of target cells was determined by; [(experimental-spontaneous) cpm / (maximum-spontaneous) cpm] x $100 \%$. 


\section{Results}

Immunisation which does not protect against DA3-MUC1 tumour growth

To examine the anti-tumour effects of MFP immunisations on the DA3-MUC1 tumour in vivo, 2 immunotherapy models were used.

In the first model, BALB/c mice with an established DA3-MUC1 tumour $\left(\sim 50 \mathrm{~mm}^{2}\right)$ were immunised 3 times (days 17, 19 and 21) with either MFP or control pH 9.0 buffer, and, tumour growth and lung metastases measured for 30 days. Unlike other tumour models [30] in the DA3-MUC1 model, there was no difference in tumour growth (Figure 1A) or the number of lung metastases (as determine by lung weight) (data not shown). Therefore, therapy with MFP was not effective at treating established DA3-MUC1 tumours.
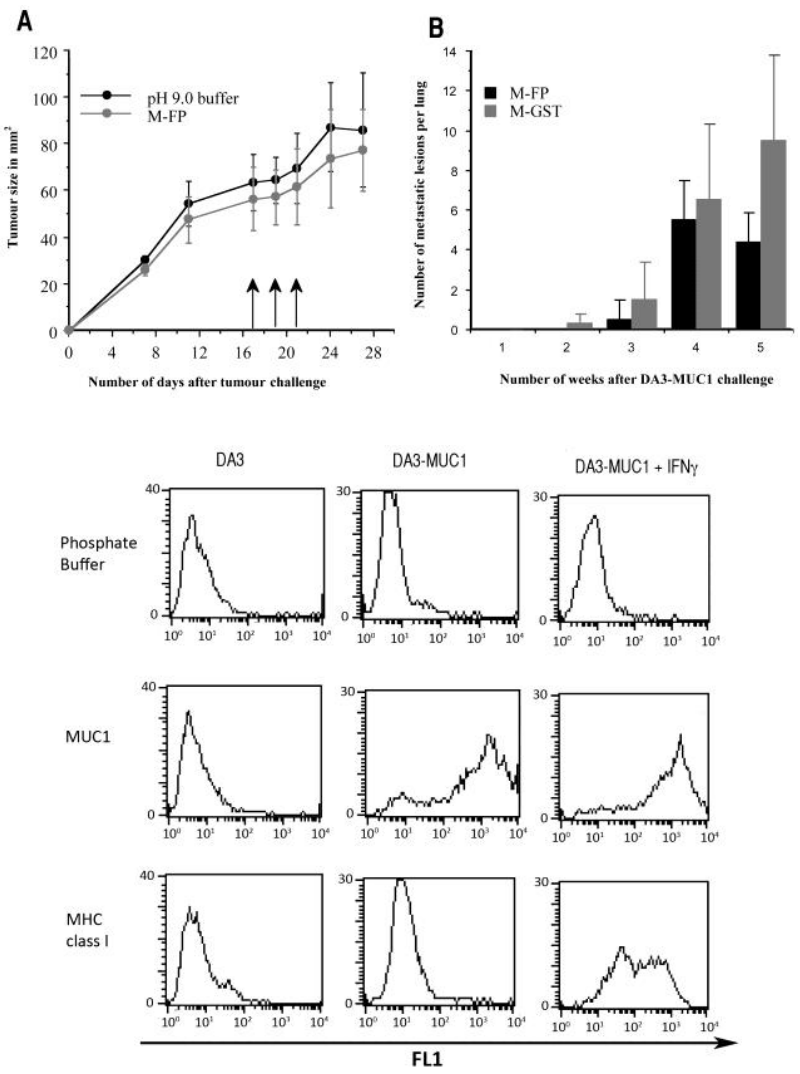

Figure 1. A - Subcutaneous DA3-MUC1 (5 x $10^{6}$ cells/mouse) tumour growth in BALB/c mice immunised with MFP. Mice with an established 17 day tumour were immunised intraperitoneally on days 17, 19 and 21 with

$5 \mu \mathrm{g}$ MFP or $p H 9.0$ buffer and tumour growth

measured. B. Lung metastases in BALB/c mice immunised with either MFP or a control M-GST 3 times (days 0, 7 and 14), then challenged with DA3-MUC1 (5 $\times 10^{6}$ cells/mouse). 4-5 mice were culled each week for 5 weeks and microscopic lung metastasis counted. Data is presented as mean +/- standard error of the mean
In the second model, BALB/c mice were immunised 3 times with either MFP or a control preparation, M-GST, and challenged with $5 \times 10^{6}$ DA3-MUC1 tumour cells subcutaneously. Metastatic lung nodules from 4-6 mice per week were examined microscopically for five weeks (Figure 1B). Immunisation (prophylactic model) with MFP did not protect mice challenged with DA3-MUC1 from developing lung metastases as assessed by the number of lung metastases per lung compared to immunised control mice.

From these studies, it was concluded that immunisation with MFP could not induce tumour protection in mice challenged with DA3MUC1 tumour cells, nor could it offer protection against an established DA3-MUC1 tumour. These results were in contrast to findings in all other $\mathrm{MUCl}^{+}$tumour models investigated, where immunisation with MFP was able to successfully induce anti-tumour immunity and tumour protection in vivo [14-23, 26, 31]. It was hypothesised that DA3-MUC1 tumours were not immunogenic due to a decrease in either costimulatory or MHC molecules on their surface. To test these hypotheses, the DA3MUC1 tumour was characterised for cell surface molecule expression in vitro and in vivo.

\section{DA3-MUC1 tumour cells express high levels of MUC1 but do not express MHC class I}

In vitro characterisation of DA3-MUC1. The DA3-MUC1 metastatic cell line was analysed for expression of human MUC1, MHC class I and other cell surface markers by flow cytometry (Table 1 and Figure 2). MUC1 is highly expressed on the surface $(>85 \%)$ of DA3-MUC1 cells compared to $<2 \%$ on nontransfected parental DA3 cells. In contrast, MHC class I expression was considerably decreased in both DA3-MUC1 cells (6\%) and non transfected DA3 cells $(<3 \%)$. There was no detectable MHC class II, B7.1, ICAM-2, CD28, LFA-2 or CTLA-4 on DA3 or DA3-MUC1 tumour cells (Table 1). Phosphate buffer was used as a control for non-specific (Fab') $)_{2}$ FITCconjugate binding . 
Table 1

In vitro expression of cell surface markers on DA3 and DA3-MUC1 tumour cells cultured with or without $20 \mathrm{ng} / \mathrm{ml}$ IFN- $\gamma$ for $72 \mathrm{~h}$. Values represent the percentage of cells positive for each antibody determined by flow cytometry

\begin{tabular}{|c|c|c|c|}
\hline Cell Surface Markers & DA3 $(\%)$ & DA3-MUC1 $(\%)$ & DA3-MUC1+IFN- $\gamma(\%)$ \\
\hline negative control & 1.94 & 3.12 & 2.71 \\
\hline MUC1 & 3.36 & 87.73 & 93.6 \\
\hline MHC class I & 2.98 & 5.67 & 76.85 \\
\hline MHC class II & 3.81 & 3.72 & 2.01 \\
\hline B7.1 & 1.49 & 3.03 & 1.67 \\
\hline ICAM 2 & 3.70 & 4.42 & 2.75 \\
\hline CD28 & 4.13 & 5.22 & 4.03 \\
\hline LFA-2 & 2.27 & 3.09 & 2.12 \\
\hline CTLA-4 & 4.81 & 6.09 & 3.70 \\
\hline
\end{tabular}

DA3
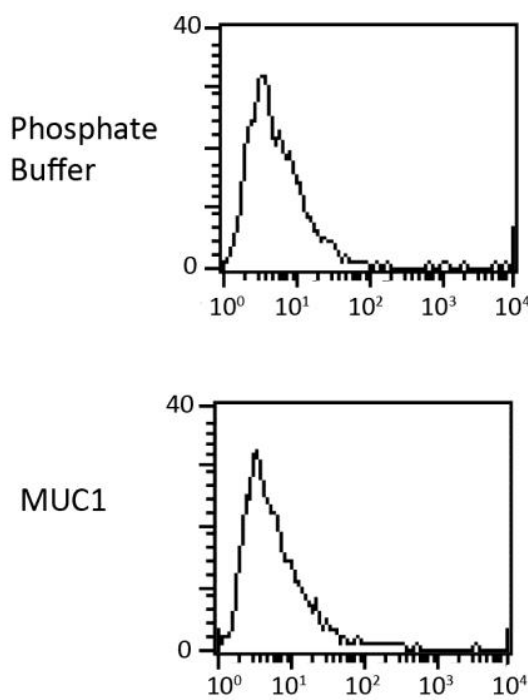

MUC1

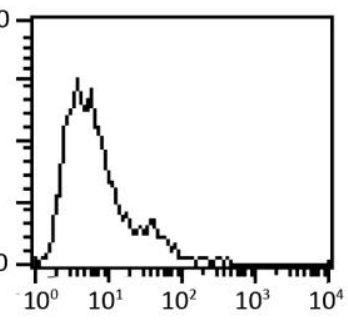

DA3-MUC1
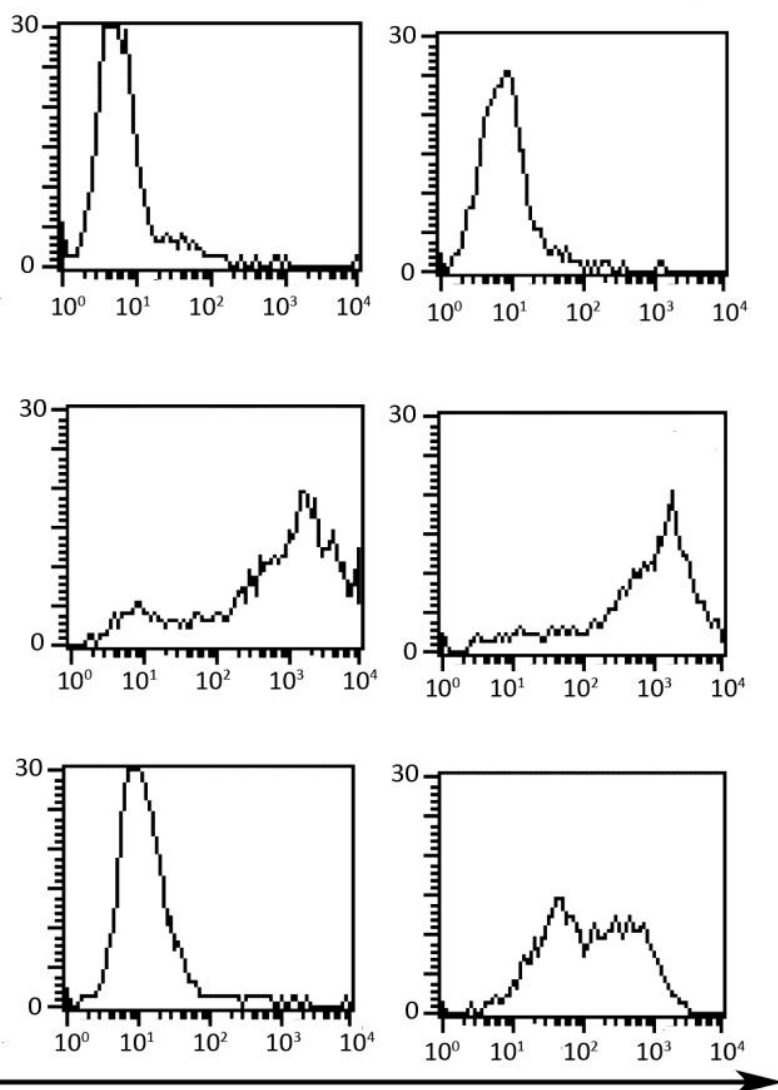

FL1

Figure 2 - Flow cytometric analysis of in vitro expression of cell surface MUC1 and MHC class I on DA3-MUC1 cells cultured with or without $20 \mathrm{ng} / \mathrm{ml}$ IFN $\gamma$ for $72 \mathrm{~h}$. The non transfected parental cell line, DA3 was used as a control. Phosphate buffer represents negative control binding of FITC-conjugated sheep (Fab') 2 anti-mouse (1/50) to the tumour cell lines

In vivo characterisation of DA3-MUC1. To characterise the DA3-MUC1 tumour in vivo, $\mathrm{BALB} / \mathrm{c}$ mice were challenged with $5 \times 10^{6}$ metastatic cells and tumour growth monitored for 10 weeks (Figure 3A). Mice had palpable subcutaneous tumours after 2-3 weeks and were culled after 10 weeks and their subcutaneous tumours and lungs removed for tumour analysis. 


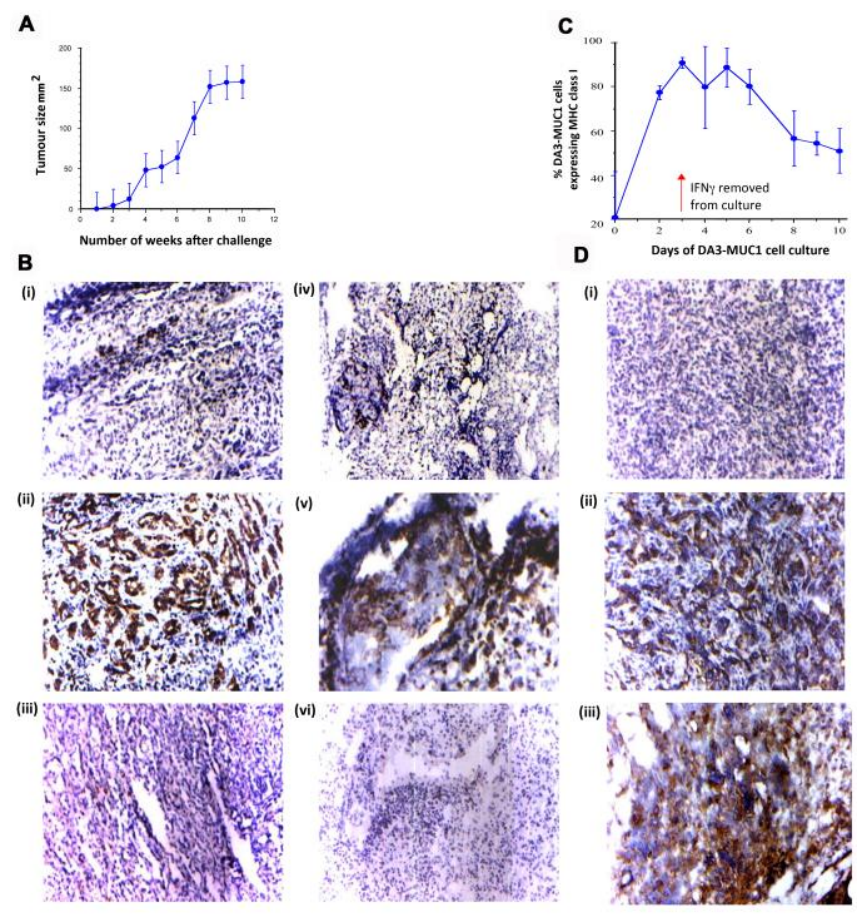

Figure 3ABCD - Tumour growth in BALB/c mice challenged with $5 \times 10^{6} \mathrm{DA3}-\mathrm{MUC1}$ cells. B. MUC1 and class I $\left(H 2^{d}\right)$ surface expression on DA3-MUC1 tumour cells determined by immunoperoxidase staining; data is presented as mean +/- standard error of the mean. DA3-MUC1 tumour cells from the site of a BALB/c subcutaneous tumour were stained for, $\boldsymbol{B}(\boldsymbol{i})$ negative control, $\boldsymbol{B}(\boldsymbol{i i}) \mathrm{MUC1}$ expression using biotinylated-BC2 and $\boldsymbol{B}(\mathrm{iii}) \mathrm{MHC}$ class $I$ expression using biotinylated-34.1.2s. DA3-MUC1 lung metastases were stained for, $\boldsymbol{B}(\boldsymbol{i v})$ negative control, $\boldsymbol{B}(\boldsymbol{v})$ MUC1 expression using biotinylated-BC2 and B(vi) MHC class I expression using biotinylated-34.1.2s. All images are shown at $200 x$ magnification. Non-specific binding of (Fab') ${ }_{2}$ conjugate was blocked with $10 \%$ BSA in DME and control samples were incubated with $10 \%$ BSA in DME. C. FACS analysis determining the length of time MHC class I expression remained elevated on DA3-MUC1 cells cultured with IFN- $\gamma$ in vitro. Tumour cells were cultured for $72 \mathrm{~h}$ with $20 \mathrm{ng} / \mathrm{ml} I F N-\gamma$ to increase MHC class I expression, IFN- $\gamma$ removed from culture and MHC class I expression measured daily. D. Immunoperoxidase staining of DA3-MUC1 cells pre-cultured with IFN- $\gamma$ and grown in vivo. Mice were sacrificed every three days for 10 days, tumours removed, formalin fixed and stained for, $\boldsymbol{D}(\boldsymbol{i})$ negative control, D(ii) MUC1 expression using biotinylated BC2 and D(iii) MHC class I expression using anti-H2d. Phosphate buffer was used as a negative control - binding of FITC-conjugated sheep (Fab') $)_{2}$ anti-mouse (1/50) to the tumour cells

As expected, immunoperoxidase staining for MUC1 and MHC class I expression on subcutaneous established DA3-MUC1 tumours were similar to that observed in vitro studies. DA3-MUC1 tumour cells express high levels of MUC1 (75-100\% of cells) (Figures 3B) and very little, if any, MHC class I (0-15\% of cells) (Figure 3B i-iii) on their cell surface. Lung metastases (macroscopic and microscopic) were observed 30-35 days after a subcutaneous injection of $5 \times 10^{6}$ DA3-MUC1 cells, however there was no evidence of metastases to the liver (data not shown). Immunoperoxidase staining for MUC1 and MHC class I expression on lung metastases showed MUC1 expression on $\sim 50 \%$ of tumour cells in the lung but no evidence of MHC class I expression (Figure 3B iv-vi).

\section{Elevation of MHC class I expression on DA3-MUC1 with IFN- $\gamma$}

It is clear that one of the factors hindering the immunogenicity of the DA3-MUC1 tumour was a decrease in the expression of MHC class I. Numerous studies have shown that MHC class I expression, and therefore tumour immunogencity, can be increased by culturing the tumour with recombinant IFN- $\gamma$. To determine whether MHC class I expression could be up-regulated on DA3-MUC1 tumour cells, cells were cultured with $20 \mathrm{ng} / \mathrm{ml}$ vaccinia virusIFN- $\gamma$ for $72 \mathrm{~h}$ and MHC class I expression determined using flow cytometry.

DA3-MUC1 expression of MHC class I molecules on the tumour surface could be greatly increased in vitro by culturing the DA3MUC1 cells with IFN- $\gamma$ (Table 1 and Figure 2). 
Prior to in vitro culturing with IFN- $\gamma$, only $6 \%$ of DA3-MUC1 cells expressed MHC class I on their cell surface (Figure 2), however, after culturing cells with IFN- $\gamma$ for $72 \mathrm{~h}, 77 \%$ of DA3-MUC1 tumour cells expressed MHC class I (Figure 2) and MUC1 expression still remained high (Figure 2).

To determine the length of time MHC class I expression remained elevated on DA3MUC1, tumour cells were cultured with IFN- $\gamma$ for $72 \mathrm{~h}$, removed, and then examined daily for MHC class I expression (Figure 3C). MHC class I expression at $72 \mathrm{~h}(\sim 90 \%)$ remained elevated $(>70 \%)$ for 3 days after the removal of the cytokine, after which time the expression dropped constantly to plateau at $\sim 55 \%$ by day 10.

To ensure the elevated class I levels observed in vitro could be sustained in vivo, DA3-MUC1 cells were cultured with IFN- $\gamma$ and injected subcutaneously into BALB/c mice. Tumours were examined on days 4 and 7 for MHC class I expression by immunoperoxidase staining (Figure 3D). DA3-MUC1 cells cultured with IFN- $\gamma$ expressed high levels of MHC class I molecules on $75 \%$ of tumour cells removed from the subcutaneous site on day 4 (data not shown), with $50 \%$ of tumour cells still remaining positive on day 7 (Figure 3D i, ii). In vivo expression of MUC1 on the subcutaneous tumour was not altered after culturing with IFN- $\gamma$ (Figure 3D iii). Thus, culturing DA3-MUC1 cells with IFN- $\gamma$ increases the expression of MHC class I molecules on the cell surface for at least 7 days after removal of IFN- $\gamma$ both in vitro and in vivo.

\section{T cells from MFP immunised mice lyse IFN- $\gamma$ treated DA3-MUC1 tumour cell targets}

From the data so far, it would appear that the DA3-MUC1 tumour is not immunogenic as it does not express MHC class I on its surface. However, culturing DA3-MUC1 cells with IFN- $\gamma$ increases MHC class I expression, both in vitro and in vivo for at least 7 days following removal of IFN- $\gamma$. We determined whether the level of increase in MHC class I on DA3MUC1 cells was adequate to be susceptible to MUC1 specific cytotoxic T cells (CTL) lysis.
BALB/c mice were therefore immunised with MFP and 7-10 days following the final immunisation, spleens were isolated and CTL were able to lyse DA3-MUC1 tumour cells (Figure 4A). Lysis of DA3-MUC1 tumour cells (treated with IFN- $\gamma$ ) was similar to that of P815MUC1 tumour cells $\left(\mathrm{H}-2 \mathrm{~d}^{+} \mathrm{MUC1}^{+} \mathrm{MHC}\right.$ class $\mathrm{I}^{+}$); non MUC1 transfected P815 cells (H$2 \mathrm{~d}^{+} \mathrm{MUC1}^{-}$MHC class $\mathrm{I}^{+}$) were used as a negative control. Interestingly, without culturing with IFN- $\gamma$, DA3-MUC1 were lysed by MUC1 CTL but the response was considerably weaker. Therefore, in vitro MUC1 T cell cytotoxicity to DA3-MUC1 tumours increases substantially with elevated MHC class I expression.

\section{MHC class $I$ is not sustained to induce tumour protection despite induction of CTL}

As IFN- $\gamma$ treated tumours express elevated levels of MHC class I, and in vitro, MFP can stimulate $\mathrm{MUC1}^{+} \mathrm{CTL}$ capable of lysing DA3-MUC1 target cells (Figure 4A), the antitumour effects of MFP immunisation on DA3MUC1 tumours expressing MHC class I was investigated in vivo. Mice were immunised 3 times with either MFP or a control pH 9.0 phosphate buffer and challenged with DA3-MUC1 tumour cells pre-cultured for $72 \mathrm{~h}$ with IFN- $\gamma$ to increase MHC class I expression. BALB/c mice were challenged with $5 \times 10^{6}$ DA3-MUC1 cells with elevated MHC class I expression (Figure 4B). Interestingly, a small reduction in tumour growth, which correlated with an increase in MHC class I expression (Figures 2 and 3 ), was evident between days 2 and 5 in both MFP and control pH 9.0 immunised mice (Figure 4B). A significant $(p<0.05)$ decrease in tumour burden was evident in mice immunised with MFP compared to control mice, on day 3, suggesting that elevated levels (90-95\%) of MHC class I expression on DA3-MUC1 tumour cells may increase their susceptibility to CTL lysis. However, no differences in tumour size were noted between MFP and control mice on any other days, and from day 6 onwards, DA3-MUC1 tumours continued to grow steadily which corresponded to a steady drop in surface MHC class I levels (Figure 3C) as the 
positive tumour cells lost MHC class I expression. Thus, elevated class I expression could not be sustained in vivo to induce anti-tumour CTL responses.

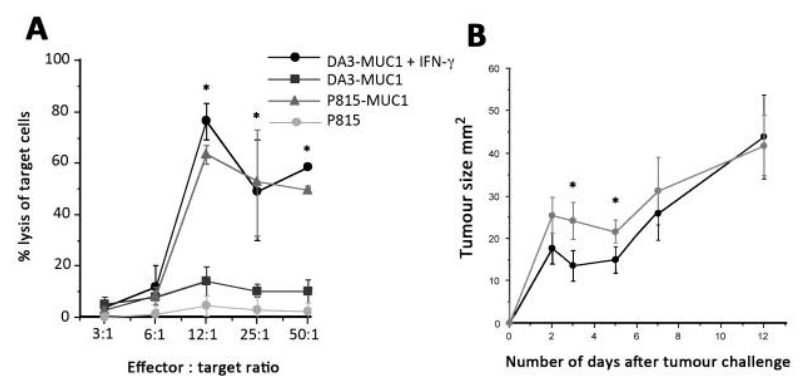

Figure $4 A B-C T L$ assay of spleen cells from effector $B A L B / c$ mice immunised with $5 \mu \mathrm{g} M F P$, on ${ }^{51} \mathrm{Cr}$ labelled DA3-MUC1 cells cultured with IFN- $\gamma$ for $72 \mathrm{~h}$, DA3-MUC1, P815-MUC1 and P815 tumour cell targets. B. Subcutaneous tumour growth of DA3-MUC1 cultured with IFN- $\gamma$ in BALB/c mice. Mice (x 10 per group) were immunised intraperitoneally on days 0,7 and 14 with either $5 \mu \mathrm{g}$ MFP (- -) or pH 9.0 buffer (-0) and challenged with $3 \times 10^{6} \mathrm{DA} 3-\mathrm{MUC1}$ tumour cells previously cultured with $20 \mathrm{ng} / \mathrm{ml}$ vaccinia virus $-I F N-\gamma$ supernatant (UV inactivated) for $72 \mathrm{~h}$. Data is presented as mean +/- standard error of the mean, * $p<0.05$

\section{Discussion}

Tumour immunotherapy with mannan MUC1 fusion protein (MFP) induces $\mathrm{CD}^{+}$cellular immunity and tumour protection in several immunogenic $\mathrm{MUC1}^{+}$tumour models (MUC1 $^{+}$P815, $\mathrm{MUC1}^{+}$RMA, MUC1 ${ }^{+}$3T3) ([14-23, 26, 31-34]. In these models, the transfection of the tumour cell lines with human MUC1 results in the spontaneous rejection of the tumours after approximately 15-20 days [34]. Yet despite this, there is still a window of between 0 and 11 days in which to observe either accelerated rejection or an absence of tumour growth in immunised mice - the basic models with which the MFP anti-tumour immune responses have been described.

In this study, the aggressive $\mathrm{MUC1}^{+}$ metastatic DA3-MUC1 tumour, was investigated as a model to study MFP immunotherapy as it is not spontaneously rejected in mice. However, in contrast to other $\mathrm{MUC1}^{+}$tumour models where MFP immunisation protected mice from a tumour challenge, DA3-MUC1 tumours grew. This resulted to determined the expression of various cell surface markers on DA3-
MUC1, required to induce cell mediated immunity. Both in vitro and in vivo studies confirmed that in contrast to other $\mathrm{MUC1}^{+}$tumour models, DA3-MUC1 has a low expression of cell-surface MHC class I which results in reduced immunogenicity in vivo. However, treatment with IFN- $\gamma$ in vitro upregulates MHC class I expression which can be sustained for several days in the absence of IFN- $\gamma$

Initial immunotherapy studies demonstrated that mice immunised with MFP and then challenged with DA3-MUC1 tumours were not protected from tumour growth. Similarly in a therapy experiment, 3 injections with MFP was also inadequate in decreasing tumour burden in mice with established DA3-MUC1 tumours. These findings were unlike other studies with MFP, whereby mice immunised with MFP were totally protected against a challenge of $\mathrm{MUC1}^{+} 3 \mathrm{~T} 3$ tumours $[20,21]$ and the induction of a $\mathrm{CD}^{+}$cellular immune response caused the regression of established 15 day-old $\mathrm{MUC1}^{+} \mathrm{P} 815$ tumours in DBA/2 mice [31].

In vitro and in vivo characterisation of DA3-MUC1 indicated that the tumour was weakly immunogenic because even though high surface levels of MUC1 were expressed (> 85\%), there were low levels of all other cell surface molecules needed for $\mathrm{T}$ cell activation including MHC class I $(<6 \%)$, MHC class II, CD80, ICAM-2, CD28, LFA-2 and CTLA-4. Similarly, metastatic lung nodules induced by DA3-MUC1 again demonstrated MUC1 expression to be present on $50 \%$ of metastatic cells but there was no MHC class I expression. The absence, or relatively low expression of these molecules on the tumour cell surface causes anergy in any activated T cells and is an effective mechanism many tumours have evolved to evade the immune system [7].

However, tumour immunogenicity can be successfully increased by up-regulating the expression of these molecules (particularly MHC and costimulatory molecules) by either gene transfection or culturing with cytokines specifically IFN- $\gamma[5,6,9,12]$. Therefore, to increase the expression of MHC class I on DA3-MUC1 cells, cells were cultured with IFN- $\gamma$. Culturing DA3-MUC1 with IFN- $\gamma$ increased expression of MHC class I from $<16 \%$ to $>90 \%$ after $72 \mathrm{~h}$. The MHC class I expres- 
sion remained elevated for several days before declining to $50 \%$ one week after the cytokine was removed from culture. In vivo studies of MHC class I expression on DA3-MUC1 after IFN- $\gamma$ culturing, revealed a similar pattern whereby levels previously not detected in a subcutaneous tumour, were elevated to 50$75 \%$ of cells expressing MHC class I four days later, and still present on day 7. Interestingly, culturing DA3-MUC1 with IFN- $\gamma$ did not increase cell surface expression of MHC class II, CD80, ICAM-2, CD28, LFA-2 or CTLA-4 as had been previously reported in other tumour models [35].

Following the up-regulation of $\mathrm{MHC}$ class I on the surface of DA3-MUC1 tumours, MUC1 specific CTL isolated from the spleen of MFP immunised mice could lyse DA3MUC1 tumour cells cultured with IFN- $\gamma$, but not DA3-MUC1 cells which were not cultured with IFN- $\gamma$. This result was considerably higher than untreated tumour cells, demonstrating that DA3-MUC1 immunogenicity is increased in the presence of MHC class I, and can be lysed by MUC1 restricted CTL in vitro.

The lack of an effective anti-tumour response in DA3-MUC1 tumours is, in part, a result of the down-regulation in MHC class I expression which can be overcome by culturing the tumour with IFN- $\gamma$. As culturing with IFN- $\gamma$ only temporarily increases MHC class I expression, it is suggested that future studies in this model would focus on the transfection of the IFN- $\gamma$ gene into DA3-MUC1 cells. Alternatively, the decrease in DA3-MUC1 immunogenicity may also be a result of tumour-reactive $T$ cells receiving inadequate costimulation through the absence of the costimulatory molecules B7-1 and B7-2. This again can be over come through transfection with these molecules [36, 37] and is also suggested for future immunotherapy studies with MFP. Furthermore, we have not investigated whether other relevant receptors may not be expressed by DA3-MUC1 cells. Finally, DA3-MUC1 cells could be used as a model to study other mechanisms and lysis where MHC class I is not required, such as, NK cell lysis.

\section{Acknowledgments}

The research was conducted on behalf of a Research and Development Syndicate and funded by Merriton Apartments. All experimetns were conducted at the Austin Research Institute. At the time of the study CL, IM, VA, GP were at the Austin Research Institute, Heidelberg VIC Australia. CL was funded by an Australian Post-graduate Award from Victoria University of Technology, Centre for Bioprocessing and Food Technology, VIC, Australia (now known as the College of Health and Biomedicine, Victoria University, VIC Australia).

\section{REFERENCES}

1. Greenberg PD. Adoptive T cell therapy of tumors: mechanisms operative in the recognition and elimination of tumor cells. Adv Immunol. 1991; 49: 281 355.

2. Melief CJ. Tumor eradication by adoptive transfer of cytotoxic T lymphocytes. Adv Cancer Res. 1992; 58: 143-75.

3. Leung HT, Linsley PS. The CD28 costimulatory pathway. Ther Immunol. 1994; 1: 217-28.

4. Leung J, Suh WK. The CD28-B7 Family in AntiTumor Immunity: Emerging Concepts in Cancer Immunotherapy. Immune Netw. 2014; 14: 265-76.

5. Garrido F, Aptsiauri N, Doorduijn EM, Garcia Lora AM, van Hall T. The urgent need to recover MHC class I in cancers for effective immunotherapy. Curr Opin Immunol. 2016; 39: 44-51.

6. Garrido F, Romero I, Aptsiauri N, Garcia-Lora AM. Generation of MHC class I diversity in primary tumors and selection of the malignant phenotype. Int J Cancer. 2016; 138: 271-80.

7. Nawrocki S, Mackiewicz A. Genetically modified tumour vaccines--where we are today. Cancer Treat Rev. 1999; 25: 29-46.

8. Mandai M. PD-1/PD-L1 blockage in cancer treatment-from basic research to clinical application. Int $\mathbf{J}$ Clin Oncol. 2016.

9. Garrido F, Cabrera T, Concha A, Glew S, RuizCabello F, Stern PL. Natural history of HLA expression during tumour development. Immunol Today. 1993; 14: 491-9.

10. Torres LM, Cabrera T, Concha A, Oliva MR, RuizCabello F, Garrido F. HLA class I expression and HPV-16 sequences in premalignant and malignant lesions of the cervix. Tissue Antigens. 1993; 41: 6571.

11. Vlkova V, Stepanek I, Hruskova V, Senigl F, Mayerova $\mathrm{V}$, Sramek $M$, et al. Epigenetic regulations in the IFNgamma signalling pathway: IFNgamma-mediated MHC class I upregulation on tumour cells is associated with DNA demethylation of antigen-presenting machinery genes. Oncotarget. 2014; 5: 6923 35 . 
12. Wallich R, Bulbuc N, Hammerling GJ, Katzav S, Segal S, Feldman M. Abrogation of metastatic properties of tumour cells by de novo expression of $\mathrm{H}-2 \mathrm{~K}$ antigens following $\mathrm{H}-2$ gene transfection. Nature. 1985; 315: 301-5.

13. Watanabe Y, Kuribayashi K, Miyatake S, Nishihara $\mathrm{K}$, Nakayama E, Taniyama $\mathrm{T}$, et al. Exogenous expression of mouse interferon gamma cDNA in mouse neuroblastoma $\mathrm{C} 1300$ cells results in reduced tumorigenicity by augmented anti-tumor immunity. Proc Natl Acad Sci U S A. 1989; 86: 9456-60.

14. Apostolopoulos V, Xing PX, Trapani JA, McKenzie IF. Production of anti-breast cancer monoclonal antibodies using a glutathione-S-transferase-MUC1 bacterial fusion protein. Br J Cancer. 1993; 67: 713-20.

15. Apostolopoulos V, Barnes N, Pietersz GA, McKenzie IF. Ex vivo targeting of the macrophage mannose receptor generates anti-tumor CTL responses. Vaccine. 2000; 18: 3174-84.

16. Apostolopoulos V, Haurum JS, McKenzie IF. MUC1 peptide epitopes associated with five different $\mathrm{H}-2$ class I molecules. Eur J Immunol. 1997; 27: 257987.

17. Apostolopoulos V, Karanikas V, Haurum JS, McKenzie IF. Induction of HLA-A2-restricted CTLs to the mucin 1 human breast cancer antigen. J Immunol. 1997; 159: 5211-8.

18. Apostolopoulos V, Loveland BE, Pietersz GA, McKenzie IF. CTL in mice immunized with human mucin 1 are MHC-restricted. J Immunol. 1995; 155: 5089-94.

19. Apostolopoulos V, Pietersz GA, Gordon S, Martinez-Pomares L, McKenzie IF. Aldehyde-mannan antigen complexes target the MHC class I antigenpresentation pathway. Eur J Immunol. 2000; 30: 1714-23.

20. Apostolopoulos V, Pietersz GA, Loveland BE, Sandrin MS, McKenzie IF. Oxidative/reductive conjugation of mannan to antigen selects for $\mathrm{T} 1$ or $\mathrm{T} 2$ immune responses. Proc Natl Acad Sci U S A. 1995; 92: 10128-32.

21. Apostolopoulos V, Pietersz GA, Xing PX, Lees CJ, Michael M, Bishop J, et al. The immunogenicity of MUC1 peptides and fusion protein. Cancer Lett. 1995; 90: 21-6.

22. Lees CJ, Apostolopoulos V, Acres B, Ong CS, Popovski V, McKenzie IF. The effect of T1 and T2 cytokines on the cytotoxic $\mathrm{T}$ cell response to mannan-MUC1. Cancer Immunol Immunother. 2000; 48: 644-52.

23. Lees CJ, Apostolopoulos V, Acres B, Ramshaw I, Ramsay A, Ong CS, et al. Immunotherapy with mannan-MUC1 and IL-12 in MUC1 transgenic mice. Vaccine. 2000; 19: 158-62.

24. Baruch A, Hartmann M, Yoeli M, Adereth Y, Greenstein S, Stadler Y, et al. The breast cancerassociated MUC1 gene generates both a receptor and its cognate binding protein. Cancer research. 1999; 59: 1552-61.
25. Baruch A, Hartmann M, Zrihan-Licht S, Greenstein S, Burstein M, Keydar I, et al. Preferential expression of novel MUC1 tumor antigen isoforms in human epithelial tumors and their tumor-potentiating function. Int J Cancer. 1997; 71: 741-9.

26. Acres B, Apostolopoulos V, Balloul JM, Wreschner D, Xing PX, Ali-Hadji D, et al. MUC1-specific immune responses in human MUC1 transgenic mice immunized with various human MUC1 vaccines. Cancer Immunol Immunother. 2000; 48: 588-94.

27. Acres RB, Hareuveni M, Balloul JM, Kieny MP. Vaccinia virus MUC1 immunization of mice: immune response and protection against the growth of murine tumors bearing the MUC1 antigen. J Immunother Emphasis Tumor Immunol. 1993; 14: 136-43.

28. Xing PX, Tjandra JJ, Stacker SA, Teh JG, Thompson $\mathrm{CH}$, McLaughlin PJ, et al. Monoclonal antibodies reactive with mucin expressed in breast cancer. Immunol Cell Biol. 1989; 67 ( Pt 3): 183-95.

29. Ozato K, Mayer NM, Sachs DH. Monoclonal antibodies to mouse major histocompatibility complex antigens. Transplantation. 1982; 34: 113-20.

30. Rentrop M, Knapp B, Winter H, Schweizer J. Aminoalkylsilane-treated glass slides as support for in situ hybridization of keratin cDNAs to frozen tissue sections under varying fixation and pretreatment conditions. Histochem J. 1986; 18: 271-6.

31. Apostolopoulos V, Pietersz GA, McKenzie IF. Cellmediated immune responses to MUC1 fusion protein coupled to mannan. Vaccine. 1996; 14: 930-8.

32. Apostolopoulos V, McKenzie IF, Lees C, Matthaei KI, Young IG. A role for IL-5 in the induction of cytotoxic $\mathrm{T}$ lymphocytes in vivo. Eur $\mathrm{J}$ Immunol. 2000; 30: 1733-9.

33. Apostolopoulos V, Popovski V, McKenzie IF. Cyclophosphamide enhances the CTL precursor frequency in mice immunized with MUC1-mannan fusion protein (M-FP). J Immunother. 1998; 21: 10913.

34. Apostolopoulos V, Xing PX, McKenzie IF. Murine immune response to cells transfected with human MUC1: immunization with cellular and synthetic antigens. Cancer Res. 1994; 54: 5186-93.

35. Sgagias MK, Nieroda C, Yannelli JR, Cowan KH, Danforth DN, Jr. Upregulation of DF3, in association with ICAM-1 and MHC class II by IFN-gamma in short-term human mammary carcinoma cell cultures. Cancer Biother Radiopharm. 1996; 11: 177-85.

36. Chen L, Ashe S, Brady WA, Hellstrom I, Hellstrom KE, Ledbetter JA, et al. Costimulation of antitumor immunity by the B7 counterreceptor for the T lymphocyte molecules CD28 and CTLA-4. Cell. 1992; 71: 1093-102.

37. Chen L, Linsley PS, Hellstrom KE. Costimulation of $\mathrm{T}$ cells for tumor immunity. Immunol Today. 1993; 14: 483-6. 
Резиме

ИМУНОТЕРАПИЈАТА МUС1 НАСПРЕМА

МЕТАСТАТСКИОТ МОДЕЛ НА

АДЕНОКАРЦИНОМ НА ГРАДИТЕ:

ВАЖНОСТА НА IFN-ГАМА

Кетрин Ј. Лис ${ }^{1}$, Некама Смородински ${ }^{2}$, Галит Хорн ${ }^{2}$, Јан Ф. К. Мекензи ${ }^{3}$, Џефри Питерс ${ }^{4,5,6}$, Лили Стојановска ${ }^{7}$, Васо Апостолопулос ${ }^{7}$

${ }^{1}$ Тековна адреса, Регионално здравство на Ечука, Ечука, Викторија, Австралија

${ }^{2}$ Оддел за клеточно истражување и имунологија, Универзитет во Тел Авив, Тел Авив, Израел

${ }^{3}$ Тековна адреса, почесен професор, Универзитет во Мелбурн, Викторија, Австралија

${ }^{4}$ Биоорганска лабораторија и лабораторија за медицинска хемија, Институт Бурнет, Викторија, Австралија

${ }^{5}$ Оддел за патологија, Универзитет во Мелбурн, Парквил, Викторија, Австралија

${ }^{6}$ Оддел за имунологија, Универзитет Монаш, Мелбурн, Викторија, Австралија

${ }^{7}$ Центар за хронични болести, Школа за здравство и биомедицина, Универзитет Викторија, Викторија, Австралија

Имунотерапија која користи муцин 1 (MUC1) поврзан со оксидиран манан (MFP) беше испитувана кај агресивен метастатски тумор
$\mathrm{MUC1}^{+}, \mathrm{DA3}-\mathrm{MUC1}$, затоа што, за разлика од многу туморски модели на $\mathrm{MUC1}^{+}$, DA3-MUC1 не е спонтано одбиен кај глувците, што го прави алтернативен модел за студии на имунотерапија. Исто така, клетките DA3-MUC1 се отпорни на лизирање од анти-MUC1 цитотоксични Т-клетки (CTLs). Неможноста туморите DA3-MUC1 да бидат отфрлени кај глувците како и вакцинацијата за MUC1 беше припишана на недостатокот на експресија на молекулите на MHC од класа I на површината на туморските клетки. Ин витро и ин виво анализата на поткожните тумори и метастази на белите дробови покажа дека туморските клетки DA3-MUC1 имаат ниска експресија $(<6 \%)$ на МНС класа I, кои може да се регулираат (> 90\%) по култивирање co IFN- $\gamma$. Резултатите од анализата на проточната цитометрија и боењето со имунопероксидаза посочи дека ин витро нагорната регулација на МНC класа I може да се одржува до седум дена ин виво, без засегање на нивоата на експресија на MUC1 антигенот. Интересно, MUC1 специфичните CTL кои ин витро ги лизираат DA3-MUC1 целите беа воведени кај вакцинирани глувци од MFP, но не успеаја да ги заштитат глувците од туморскиот предизвик на DA3-MUC1. Овие резултати ја нагласуваат важноста на молекулите на МНС од класа I во поттикнувањето на антитуморскиот имунитет и имуниот одговор на MFP.

Клучни зборови: MUC1, MHC класа I, интерферонгама, тумор, имунотерапија 